\title{
Three new freshwater species of the genus Achnanthidium (Bacillariophyta, Achnanthidiaceae) from Taiping Lake, China
}

\author{
Pan $\mathrm{YU}^{1}$, Qingmin You${ }^{1}$, J. Patrick KocIOLEK ${ }^{2,3} \&$ Quanxi WANG ${ }^{1 *}$ \\ ${ }^{1}$ College of Life Sciences, Shanghai Normal University, Shanghai 200234, P. R. China; *Corresponding author \\ e-mail:wangqx@shnu.edu.cn \\ ${ }^{2}$ Museum of Natural History, University of Colorado, Boulder, CO 80309, USA \\ ${ }^{3}$ School of Life Science, Shanxi University, Taiyuan, P.R. China
}

\begin{abstract}
We describe three new Achnanthidium species, A. lacustre sp. nov., A. sublanceolatum sp. nov., and A. taipingensis sp. nov., from Taiping Lake, Anhui Province (China) based on light and scanning electron microscopy. A. lacustre sp. nov. belongs to the "A. minutissimum complex" of the genus, based on it having straight external distal raphe fissures and round to elliptical areolae. Both A. sublanceolatum sp. nov., and A. taipingensis sp. nov. belong to the "A. pyrenaicum complex" of the genus, based on them having transpically-elongated areolae and deflected external distal raphe fissures. All three species are sufficiently different from other similar species based on valve outline, shape of the axial and center areas, and striae density. These three new species are all observed in benthic collections from Taiping Lake.
\end{abstract}

Key words: Achnanthidium, diatom, morphology, new species, Taiping Lake, China

\section{INTRODUCTION}

The genus Achnanthidium is known from freshwaters, and species of this genus are widely distributed in various types freshwater habitats and can be common and abundant in those habitats (KARTHICK et al. 2017; LIU et al. 2016; PINSEEL et al. 2015; NovAIs et al. 2011; Potapova \& PonAder 2004; Kobayasi et al. 2006). Achnanthidium species can occur across a broad range of trophic conditions, from oligotrophic to eutrophic waters (Karthick et al. 2017; Ponader \& Potapova 2007). This genus was initially described by KüTZING (1844) as a subgenus of Achnanthes, and the species Achnanthes microcephalum KüTZING was the type species (PÉRÈs et al. 2014; KIngSton 2003). Later, Achnanthidium was elevated to the level of genus by Round et al. (1990) and Round \& BukhtiYarova (1996). Because the size of many Achnanthidium is small, and there may be few identification characteristics evident as viewed with the light microscopy (LM), and the variability of diagnostic features often overlap, this genus may be challenging to study in terms of species recognition (KARTHICK et al. 2017; MARquardt et al. 2017; Ponader \& Potapova 2007).

The genus Achnanthidium has been subdivided into three subgroups, the "Achnanthidium minutissimum complex", "A. pyrenaicum complex" and the " $A$. exiguum complex" (KARTHICK et al. 2017; PÉRÈs et al. 2014; Wojtal et al. 2011; Wojtal et al. 2010). The A. minutissimum complex has straight external distal raphe ends and, usually, linear to linear-lanceolate valve shapes, striae density increasing towards the apices and round external areolar openings (PINSEEL et al. 2015; Compère \& VAN De ViJVer 2011). Members of A. pyrenaicum complex have external distal raphe ends that are deflected or hooked to one side of the valve and slit-like areolar openings (PINSEEL et al. 2015; JÜTTNER et al. 2011; Round \& Bukhtiyarova 1996). Members of the A. exiguum complex have external distal raphe ends curved in opposite directions.

Presently, the number of species of the genus Achnanthidium is greater than 200 (MARQUARDT et al. 2017; KocioleK et al. 2018). Only a limited number of new Achnanthidium species have been described from China (e.g. LIU et al. 2016; YU et al. 2018, accepted). During a survey of the freshwater diatoms from Taiping Lake, in the framework of water quality monitoring, three unknown Achnanthidium species were encountered. The purpose of this present is to document and formally describe those species with light microscopy (LM) and scanning electron microscopy (SEM), and to compare the new species with morphologically similar taxa. 


\section{Material ANd Methods}

For this study we used samples that were collected from Taiping Lake $\left(30^{\circ} 14^{\prime}-30^{\circ} 28^{\prime} \mathrm{N}, 117^{\circ} 55^{\prime}-1118^{\circ} 12^{\prime} \mathrm{E}\right)$, located in the District of Huangshan Mountain, Southern Anhui Province, China, in May 2018. Taiping Lake is the largest artificial reservoir lake in Anhui province. In the field, several water chemistry characteristics were recorded, including: $\mathrm{pH}$, temperature, dissolved oxygen, salinity, total dissolved solids (TDS), and conductivity. These were all measured using a YSIPro Plus multiparameter meter (YSI, Ohio, USA). Diatom samples were collected from natural substrates, including stones, or from navigation buoys, by clean toothbrushes, and the samples were placed in a bottle and preserved with formalin (4\% final concentration).

In the laboratory, diatom samples were cleaned with concentrated nitric acid using the Microwave Accelerated Reaction System (Model MARS, CEM Corporation, Charlotte, USA) (PARR et al. 2004), with a pre-programmed digestion scheme (temperature, $180^{\circ} \mathrm{C}$ ) (You et al. 2015; Yu et al. 2017). Next, samples were alternately centrifuged for $5 \mathrm{~min}$ at $3500 \mathrm{rpm}$ (TDZ5-WS, Luyi Corporation, Shanghai, China) and washed six times using distilled water until the $\mathrm{pH}$ of the sample was close to neutral. Finally, the cleaned samples were kept in $95 \%$ ethanol. Cleaned diatom frustules were made mounted in Naphrax for light microscopy (LM) or air-dried onto cover slips and mounted onto alloy stubs for observation with the scanning electron microscope (SEM). LM studies were made with an Olympus BX-53 microscope fitted with DIC optics and a $100 \times$ oil immersion objectives (1.4 numerical aperture). SEM examination was made using a Hitachi SU8010 (1-2 kV, WD less than $6 \mathrm{~mm}$ ) (Tokyo, Japan). Images were compiled with Adobe Photoshop CS6. Morphological terminology follows Round et al. (1990). All of the diatom samples and permanent slides are housed in the Biology Department Diatom Herbarium, Shanghai Normal University (SHTU). Isotype material and slides has been deposited in the Kociolek Collection at the University of Colorado, Boulder (COLO).

\section{RESULTS}

Achnanthidium lacustre P. Yu, Q-M. You et Kociolek sp. nov. (Figs 1-20, 90-105)

Description: In LM (Figs 1-20), frustules are bent in girdle view with a concave raphe valve and a convex rapheless valve. Frustules are heterovalvar, monorpahid. Valves are irregularly linear-lanceolate in shape, with bluntly rounded apices. Valve length 20-23 $\mu \mathrm{m}$, breadth $3.0-3.5 \mu \mathrm{m}(\mathrm{n}=200)$. Both valves possess a linear axial area which widens slightly towards the central area. On the raphe valve, central area is a small oval in shape forming an elliptical fascia. Striae are radiate along the whole valve, and the middle striae are more distantly placed than others. Striae number 27-29 in $10 \mu \mathrm{m}$ at the center, up to $28-32$ in $10 \mu \mathrm{m}$ near the apices on the raphe valve. On the rapheless valve, striae are radiate throughout the entire valve, becoming denser towards the valve apices, 26-29 in $10 \mu \mathrm{m}$ in the middle and 28-30 in $10 \mu \mathrm{m}$ near the apices. Individual areolae are not visible in LM.
SEM observations of both valves show the valve face: mantle junction bordered by a narrow hyaline area (Figs $90,98)$, and the mantle has single row of linear areolae (Figs 100,102). On the exterior of the raphe valve, the raphe is filiform and straight (Fig 90), proximal raphe ends are straight, and simple (Fig 92), and the distal raphe ends are straight and extend on the valve mantle (Fig. 93). Striae are uniseriate, comprised of 2-3 round to oblong areolae in the center of the valve (Fig 93), and 1-3 large, irregularly-round or transapically elongate areolae elsewhere (Fig 93). Some striae have one slitlike areolae on the valve mantle (Figs 92-93). Areolar occlusions are positioned within the opening and can be seen from the exterior (Fig 96). Internally, the raphe terminates distally as elevated helictoglossae (Figs 91, 94), and the proximal raphe endings are short, deflected in opposite directions (Figs 91, 95). Areolae are large round to oblong in shape and the openings are occluded with fine hymenate structures that include small openings around the periphery (Fig 97).

On the external of the rapheless valve, the axial area is linear, widening slightly towards the central area (Fig 98). Striae are uniseriate, comprised of 4-5 round to transapically elongate areolae in the middle part of the valve (Figs 98, 102), and 1-3 irregularly round or transapically elongate areolae at the ends (Fig 100). Some striae have one slit-like areola on the valve mantle (Figs $100,102)$. The areolae are occluded with fine hymen structure that can be seen externally (Fig 104). Internally, areolae are round to transapically-elongate, occluded on valve face and mantle, and the occlusions are comprised of a fine hymenate structure (Figs 99, 101, 103, 105).

Holotype: SHTU!, slide TPH-1805009!, holotype illustrated in Figs 2, 11.

Isotypes: COLO! slide 628097, Kociolek Collection, University of Colorado, Museum of Natural History Diatom Herbarium, Boulder, USA.

Type locality: CHINA. Taiping Lake, Anhui Province, $30^{\circ} 23^{\prime} 07^{\prime \prime} \mathrm{N}, 118^{\circ} 02^{\prime} 26^{\prime \prime} \mathrm{E}$, altitude: $210 \mathrm{~m}$, collected by Q.X. Wang et al., 21th May 2018.

Etymology: The species is named for it being found in a lake.

Ecology: Collected in two samples (TPH-20180509; TPH-201805011) on stones and navigation buoys. $\mathrm{pH}$ 8.5 , water temperature $25.5^{\circ} \mathrm{C}$, Salinity $0.05 \%$, TDS $69.6 \mathrm{mg} . \mathrm{l}^{-1}$, Conductivity $108 \mu \mathrm{s} . \mathrm{cm}^{-1}$ ).

Distribution: So far, the new species is known only from the two sampling localities.

\footnotetext{
Achnanthidium sublanceolatum P. Yu, Q-M. You et Kociolek sp. nov. (Figs 21-55, 106-123)

Description: In LM (Figs 21-55), Frustules are heterovalvar, monoraphid. Valves are linear-lanceolate in shape, with rounded or weakly protracted apices. Valve length $18-35 \mu \mathrm{m}$, breadth 4.0-4.5 $\mu \mathrm{m}(\mathrm{n}=300)$. The raphe valve is concave, and the axial area is narrow,
} 
linear-lanceolate, widening slightly towards the central area. Striae nearly parallel, $20-23$ in $10 \mu \mathrm{m}$ at the middle portion, 36-42 in $10 \mu \mathrm{m}$ near the apices, on the raphe valve. The rapheless valve is convex, with narrow linear-lanceolate axial area weakly expanded at the middle portion of the valve. Striae are nearly parallel, 21-24 in $10 \mu \mathrm{m}$ in the center, and 30-36 in $10 \mu \mathrm{m}$ near the apices. Areolae are not visible in LM.

In the SEM, both valves have a narrow hyaline area at the valve face: mantle junction (Figs 106, 115). Raphe valve: Externally, the raphe is filiform and straight (Fig 106), distal raphe ends are deflected to the same side at an angle of nearly $90^{\circ}$, and the proximal raphe ends are straight and teardrop-shaped (Figs 106, 108, 110). Striae are uniseriate, containing 3-4 transapically-oriented areolae in the middle portion of the valve, and 1-2 long narrow areolae at the apices (Figs 108, 110, 112-113). Valve mantle with a single row of linear areolae extended around the apices with small interruption at the ends (Fig. 108). Internally, the raphe terminates in raised helictoglossae close to apices (Figs 107, 109), and proximal raphe ends are weakly deflected in opposite directions (Figs 107, 111). Areolae are transapically elongate in the central portion of the valve and becoming larger and oblong at the apices (Figs 109, 111). Areolar openings have fine, complex hymenate occlusions (Fig 114).

Rapheless valve: Externally, the axial area is linear-lanceolate, being weakly expanded in the central area and the apices (Figs 115, 117-118, 122). Striae are uniseriate, comprised of 2-5 narrow and linear areolae in the central area (Fig. 122), and 1-2 large linear areolae at the apices (Fig. 117-118). Valve mantle with a single row of linear areolae extended around apices (Figs 117-119). Internally, areolae are transapically oval in the center of the valve (Fig 123) and large irregular and oblong at the ends (Fig 120). Areolar openings have fine, complex hymenate occlusions (Fig 121).

Holotype: SHTU!, slide TPH-1805011!, holotype illustrated in Figs 21, 38.

Isotypes: COLO! slide 628098, Kociolek Collection, University of Colorado, Museum of Natural History Diatom Herbarium, Boulder, USA.

Type locality: CHINA. Taiping Lake, Anhui Province, $30^{\circ} 22^{\prime} 18^{\prime \prime N}, 118^{\circ} 06^{\prime} 51^{\prime \prime E}$, altitude: $210 \mathrm{~m}$, collected by Q.X. Wang et al., 21th May 2018.

Etymology: The species name is based on the outline shape of the valves.

Ecology: Collected in two samples (TPH-201805008; TPH-201805011) on navigation mark. $\mathrm{pH} 8.5$, water temperature $25.5^{\circ} \mathrm{C}$, Salinity $0.05 \%$, TDS $69.6 \mathrm{mg} . \mathrm{l}^{-1}$, Conductivity $108 \mu \mathrm{s} . \mathrm{cm}^{-1}$ ).

Distribution: So far, the new species is only known from the two samples localities.
Achnanthidium taipingensis P. Yu, Q-M. You et Kociolek sp. nov. (Figs 56-89, 124-146)

Description: In LM (Figs 56-89), frustules are heterovalvar, monoraphid. The raphe valve is concave and the rapheless valve is convex. Valves linear to linear-elliptic in shape, with broadly rounded ends. Valve length 12-24 $\mu \mathrm{m}$, breadth $3.5-4.0 \mu \mathrm{m}(\mathrm{n}=300)$. Raphe valve with a narrow, linear-lanceolate axial area which is weakly expanded at the middle portion of the valve. Striae are nearly parallel, becoming denser towards apices, 21-25 in $10 \mu \mathrm{m}$ at center, $28-32$ in $10 \mu \mathrm{m}$ near the apices. Rapheless valve with narrow, linear axial area which is weakly expanded at the middle portion of the valve. Striae density is $20-24$ in $10 \mu \mathrm{m}$ at the center, up to 26-30 in $10 \mu \mathrm{m}$ at the apices.

In the SEM, the frustule is slightly bent ventrally in girdle view (Fig.139). On the both valves, the valve mantle has a single row of linear areolae (Figs 139, 141), but there is a small depression on one side of the raphe (Figs 126-127) that is absent at the apices of rapheless valveS (Figs 142-143). Externally, the raphe is filiform, straight (Fig 124), and has distal raphe ends deflected to the same side. On the side of the deflection there is a depression near the distal raphe ends (Figs 126-127). The proximal raphe ends are straight and teardrop-shaped (Figs 128-130). Areolae are small, round to transapically-oriented, the uniserate striae are composed of $1-5$, usually $4-5$, areolae in the middle portion of the valve (Figs 128-130), and 1-4 areolae at the apex (Figs 126-127). Internally, distal raphe ends terminate in raised helictoglossae (Figs 131, 133), while the proximal raphe ends are very weakly deflected in opposite directions (Figs 131, 135).

On the exterior of the rapheless valve, the areolae are small, transapically-oriented, and the uniseriate striae contain 2-6, usually 4-5, areolae at the center (Figs 145-146), and 1-3 areolae at the apices (Figs 142-143). On the both interior of both valves, areolae are occluded by hymenes perforated by delicate slits, and each hymene joins with the adjacent hymene (Fig. 137-38).

Holotype: SHTU!, slide TPH-1805014!, holotype illustrated in Figs 60, 73.

Isotypes: COLO! slide 628099, Kociolek Collection, University of Colorado, Museum of Natural History Diatom Herbarium, Boulder, USA.

Type locality: CHINA. Taiping Lake, Anhui Province, $30^{\circ} 21^{\prime} 46^{\prime \prime} \mathrm{N}, 117^{\circ} 57^{\prime} 34^{\prime \prime E}$, altitude: $210 \mathrm{~m}$, collected by Q.X. Wang et al., 21th May 2018.

Etymology: The species is named for Taiping Lake.

Ecology: Collected in two samples (TPH-201805008; TPH-201805014) on navigation mark. pH 8.5, water

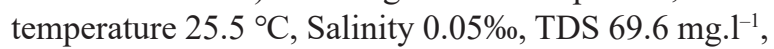
Conductivity $108 \mu \mathrm{s} . \mathrm{cm}^{-1}$ ).

Distribution: So far, the new species is known only from the two sample localities. 


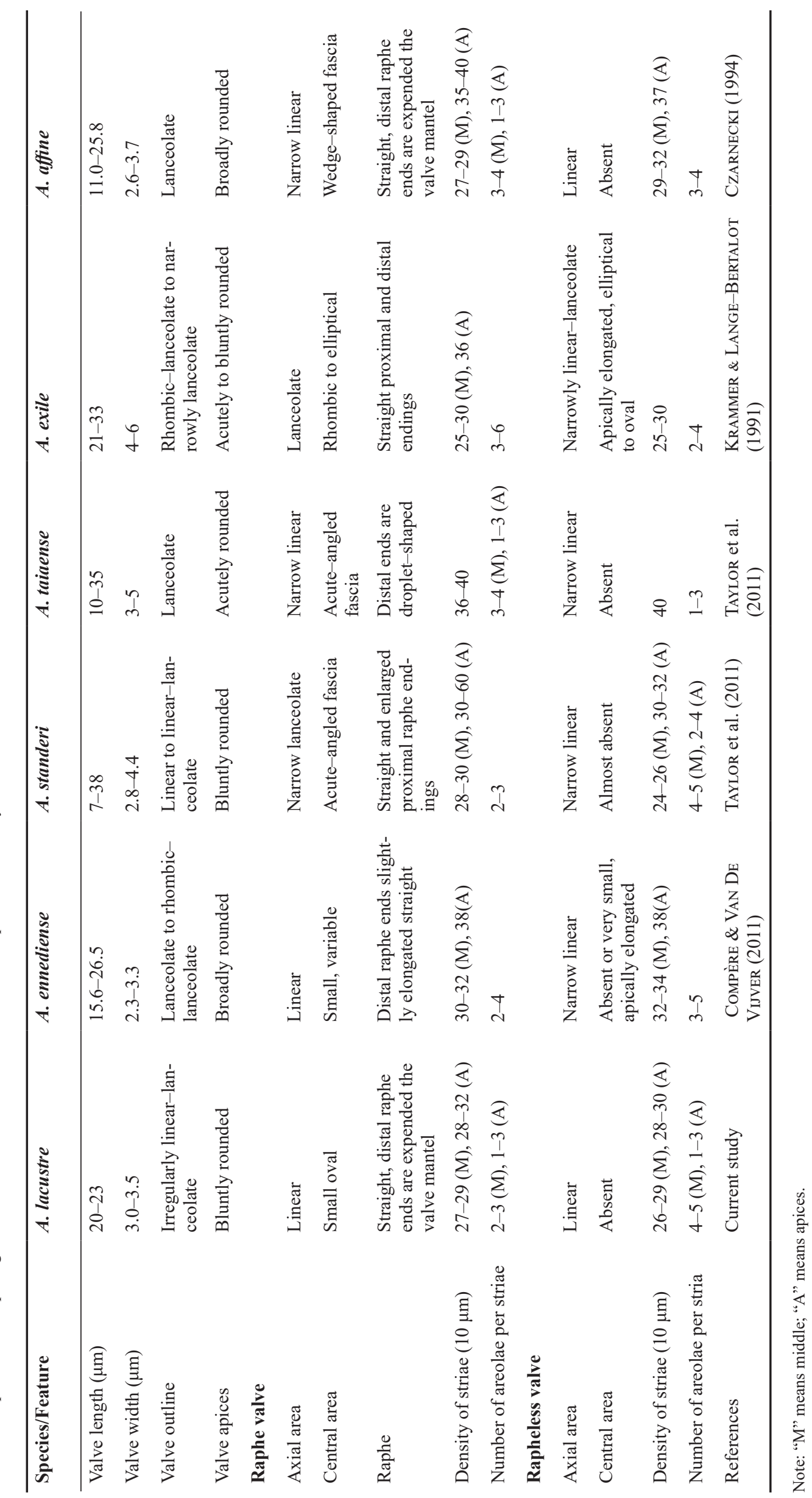




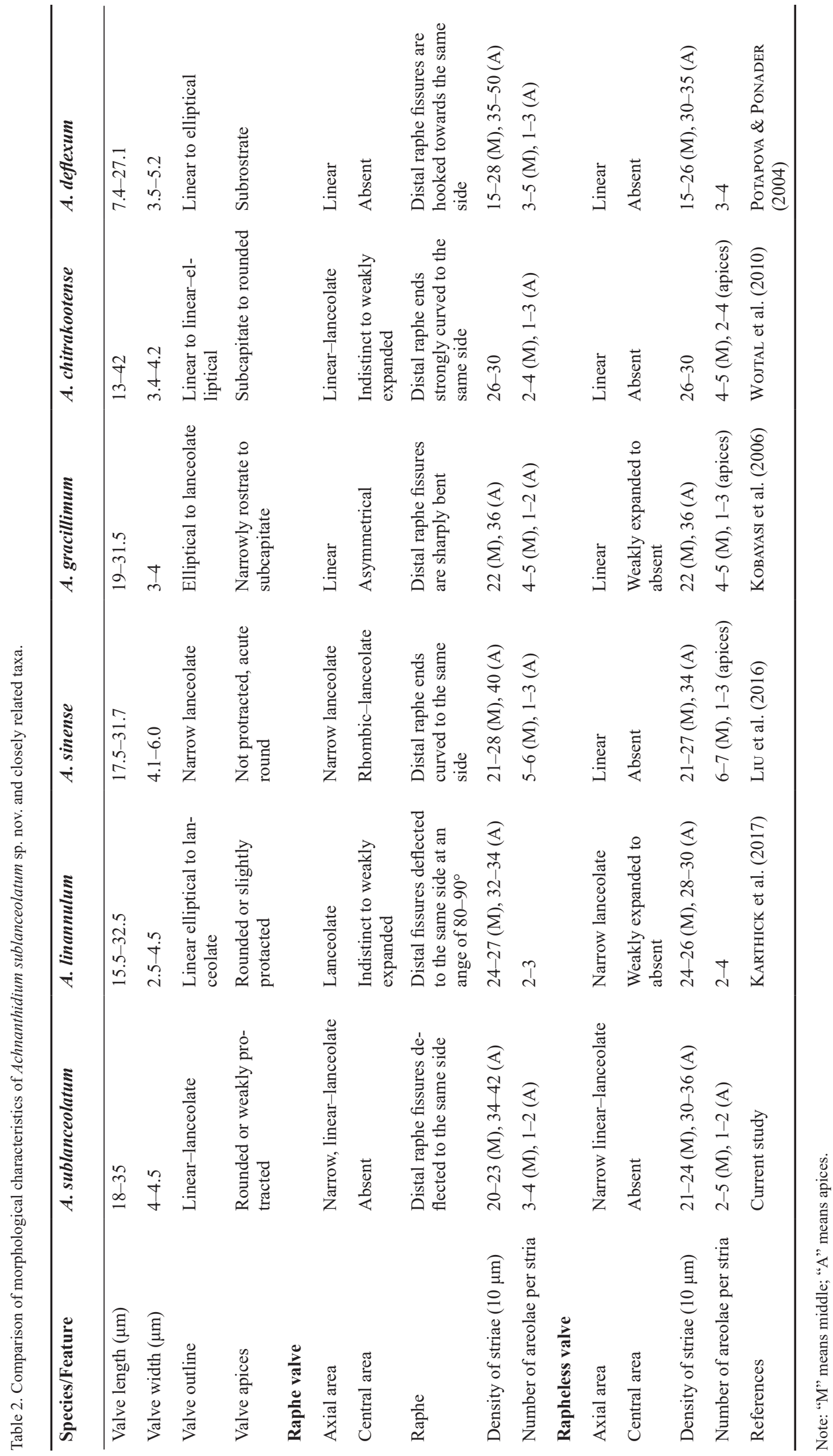




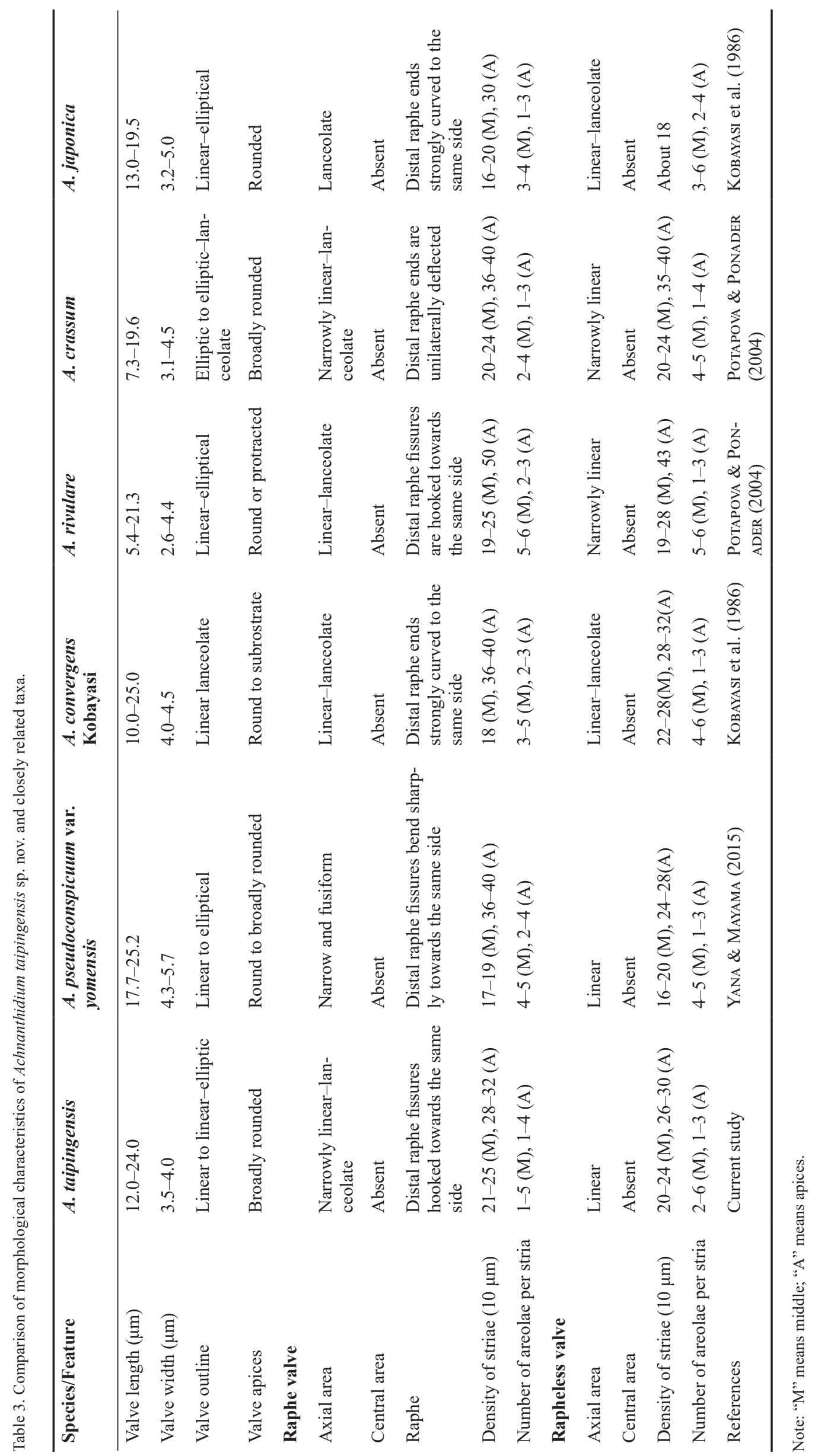




\section{Discussion}

The three new species possess characters that support their assignment to the genus Achnanthidium, including, having small linear-lanceolate to lanceolate elliptic valves, shallow V-shaped valve in girdle view, uniseriate striae, a fine raphe and straight or deflected external distal raphe fissures (ViJver et al. 2011; PonAdER \& PotAPova 2007). A. lacustre belongs to the "A. minutissimum complex" based on its possession of straight external distal raphe fissures, while $A$. sublanceolatum and A. taipingensis belong to the "Achnanthidium pyrenaicum complex" based on them having deflected external distal raphe fissures. $A$. lacustre is similar to a few species, including $A$. ennediense (Compère) Compère et Van De Vijver (COMPÈre \& VAN De ViJVer 2011), A. standeri Taylor, Morales et Ector (TAYLOR et al. 2011), A. taiaense Taylor, Morales et Ector (TAYLOR et al. 2011), A. exile (KüTZING) Heiberg (KRAMMER \& LANGE-BERTALOT 1991) and $A$. affine (Grunow) Czarnecki (CzARNECKI 1994). To facilitate comparison between $A$. lacustre sp. nov. and these similar species their morphological characteristics are summarized in Table 1. In valve shape, A. lacustre sp. nov. can easily be separated from other similar species with irregularly linear-lanceolate outlines. A. ennediense, for example, has valves with lanceolate to rhombic-lanceolate outlines while the valve of $A$. standeri are linear to linear-lanceolate, $A$. taiaense are lanceolate, $A$. exile are rhombic-lanceolate to narrowly lanceolate, and $A$. affine with a lanceolate valve. $A$. lacustre sp. nov. and $A$. standeri have bluntly-rounded apices, while $A$. ennediense and $A$. affine have valves with broadly rounded ends. $A$. taiaense and $A$. exile bear acutely rounded apices, helping to distinguish them from $A$. lacustre sp. nov. In the raphe valve, the center area is small oval of $A$. lacustre sp. nov. which different other species, $A$. ennediense with a oval to very slightly apically elongated center area, $A$. standeri and $A$. taiaense have a acute-angled fascia in middle portion, $A$. exile with rhombic to elliptical center area, and $A$. affine with a large wedge-shaped fascia in middle portion. In addition, the striae density at the apices of $A$. lacustre sp. nov. is less $(28-32 / 10 \mu \mathrm{m})$ at the apices than $A$. ennediense $(38 / 10$ $\mu \mathrm{m})$, A. standeri $(30-60 / 10 \mu \mathrm{m})$, A. taiaense $(36-40 / 10$ $\mu \mathrm{m})$, A. exile $(36 / 10 \mu \mathrm{m})$, and $A$. affine $(35-40 / 10 \mu \mathrm{m})$. Furthermore, the striae density of $A$. lacustre sp. nov. is less $(26-29 / 10 \mu \mathrm{m}$ at the middle, $28-30 / 10 \mu \mathrm{m}$ at the apices) than $A$. ennediense (32-34/10 $\mu \mathrm{m}$ at the middle, $38 / 10 \mu \mathrm{m}$ at the apices), $A$. standeri (30-32/10 $\mu \mathrm{m}$ at the apices), $A$. taiaense (40/10 $\mu \mathrm{m}$ throughout the length of the valve) and $A$. affine (29-32/10 $\mu \mathrm{m}$ at the middle, 37/10 $\mu \mathrm{m}$ at the apices), but the striae density of the middle portion of $A$. lacustre sp. nov. is higher than $A$. standeri (24-26/10 $\mu \mathrm{m})$. On the rapheless valve, A. lacustre sp. nov., A. standeri, $A$. taiaense and $A$. affine all lack a distinguished central area, but valves of $A$. ennediense have a small apically-elongated central area, and in $A$. exile the valves have a apically-elongated, elliptical to oval central area.

There are five species that might be confused with $A$. sublanceolatum sp. nov., namely A. linannulum Karthick, Taylor et Hamilton (KARTHICK et al. 2017), A. sinense Liu et Blanco (LIU et al. 2016), A. gracillimum (Meister) Lange-Bertalot (KoBAYAsI et al. 2006), A. chitrakootense Wojtal, Lange-Bertalot et Nautiyal (WoJtal et al. 2010) and A. deflexum (Reimer) Kingston (Potapova \& Ponader 2004), and we compare them morphologically in Table 2. In LM, valves of A. sublanceolatum sp. nov. are wider $(4-4.5 \mu \mathrm{m})$, as compared to A. gracillimum (3-4 $\mu \mathrm{m})$ and $A$. chitrakootense (3.4-4.2 $\mu \mathrm{m})$, and narrower than either $A$. sinense $(4.1-6.0 \mu \mathrm{m})$ or A. deflexum (3.5-5.2 $\mu \mathrm{m})$. There is a difference in valve outline between $A$. sublanceolatum sp. nov. and these other species, with valves of $A$. sublanceolatum sp. nov. being linear-lanceolate with rounded apices. A. linannulum possesses linear elliptical to lanceolate valves that have rounded or slightly protracted apices, $A$. sinense have a narrow lanceolate valve and acutely round ends, $A$. gracillimum bears elliptical to lanceolate valve and narrowly rostrate to subcapitate ends, $A$. chitrakootense has valves with linear to linear-elliptical and subcapitate to rounded ends, and $A$. deflexum possess a linear to elliptical valve and a subrostrate apices. On the raphe valve, $A$. sublanceolatum sp. nov. and $A$. deflexum usually have no distinct central area, while the central areas of $A$. linannulum and $A$. chitrakootense are indistinct to weakly expanded. In $A$. sinense the central area is rhombic-lanceolate, while in A. gracillimum the central area is asymmetrical. Moreover, the striae density at the apices of $A$. sublanceolatum sp. nov. is less $(34-42 / 10 \mu \mathrm{m})$ than $A$. sinense $(40 / 10 \mu \mathrm{m})$ and $A$. deflexum (35-50/10 $\mu \mathrm{m})$, but higher than $A$. linannulum (32-34/10 $\mu \mathrm{m})$ and $A$. chitrakootense (26-30/10 $\mu \mathrm{m})$. There are also additional features that distinguish this new species from other similar species (Table 2).

Species similar to $A$. taipingensis sp. nov. are $A$. pseudoconspicuum var. yomensis Yana et Mayama (YANA \& MaYAma 2015), A. convergens Kobayasi (KoBAYASI et al. 1986), A. rivulare Potapova et Ponader (Potapova $\&$ Ponader 2004) and $A$. crissum (Hustedt) Potapova et Ponader (Potapova \& Ponader 2004), A. japonica Kobayasi (KoBAYASI et al. 1986). This group of species is compared in Table 3. Externally, on the raphe valve, $A$. taipingensis sp. nov. has a depression near the terminal raphe fissures, a feature which distinguishes it from other, similar species. In addition, the internal proximal raphe fissures of $A$. taipingensis sp. nov. are only very weakly deflected in opposite directions, but in other, similar species the internal proximal raphe ends are distinctly deflected in opposite directions. Additionally, the striae density at the middle of the valves of $A$. taipingensis sp. nov. is higher $(21-25 / 10 \mu \mathrm{m})$ than $A$. pseudoconspicuum var. yomensis $(17-19 / 10 \mu \mathrm{m})$, A. convergens $(18 / 10 \mu \mathrm{m})$, and $A$. japonica $(16-20 / 10 \mu \mathrm{m})$, and the striae density at the ends of $A$. taipingensis sp. nov. is lower $(28-32 / 10 \mu \mathrm{m})$ than $A$. pseudoconspicuum var. 
yomensis $(36-40 / 10 \mu \mathrm{m})$, A. convergens $(36-40 / 10 \mu \mathrm{m})$, $A$. rivulare $(50 / 10 \mu \mathrm{m})$, and $A$. crassum $(36-40 / 10 \mu \mathrm{m})$. On the rapheless valve, the striae density at the meddle of $A$. taipingensis sp. nov. is higher $(20-24 / 10 \mu \mathrm{m})$ than A. pseudoconspicuum var. yomensis (16-20/10 $\mu \mathrm{m})$, and A. japonica $(18 / 10 \mu \mathrm{m})$. Also, the striae density at the apices of $A$. taipingensis sp. nov. is less $(26-30 / 10 \mu \mathrm{m})$ than $A$. rivulare $(43 / 10 \mu \mathrm{m}), A$. crassum $(35-40 / 10 \mu \mathrm{m})$, and $A$. convergens $(28-32 / 10 \mu \mathrm{m})$, and higher than $A$. pseudoconspicuum var. yomensis $(24-28 / 10 \mu \mathrm{m})$ and $A$. japonica $(18 / 10 \mu \mathrm{m})$.

This paper represents the first published treatment of diatoms from Taiping Lake, Southern Anhui Province, China. The three new Achnanthidium species were abundant in the samples studied, and there are some other monoraphid species that co-occur with these new species. The co-occurring monoraphid taxa include, Achnanthidium caledonicum LANGE-BERTALOT, A. pyrenaicum (Hustedt) Kobayasi, A rivulare Potapova et Ponader and A. duthiei (Sreen.) Edlund. We will continue to study the diatom diversity of the Taiping Lake.

\section{ACKNOWLEDGEMENTS}

This research was funded and supported by National Natural Science Foundation of China (No. 31770222), National basic science and technology work (2013FY110400), and Shanghai Engineering Research Center of Plant Germplasm Resources (17DZ2252700). We would like to thank Dr. Wanting Pang, Yue Cao, Lixuan Zhang, Yang Yu, and Lin Cui for help in the field and in the preparation of samples.

\section{REFERENCES}

Compère, P. \& VAN De ViJver, B. (2011): Achnanthidium ennediense (Compère) Compère et Van de Vijver comb. nov. (Bacillariophyceae), the true identity of Navicula ennediensis compère from the Ennedi mountains (Republic of Chad). - Algological Studies 136/137: 5-17.

CzarneCKI, D.B. (1994): The freshwater diatoms culture collection at Loras College, Dubuque, Iowa. - In: KockioLEK, J.P. (ed.): Proceedings of the 11th International Diatom Symposium. - Memoirs of the California Academy of Sciences 17: 155-174.

JÜtTner, I.; Chimonides, J. \& Cox, J. (2011): Morphology, ecology and biogeography of diatom species related to Achnanthidium pyrenaicum (Hustedt) Kobayasi (Bacillariophyceae) in streams of the Indian and Nepalese Himalaya. - Algological Studies 136/137: 45-76.

Karthick, B.; TAYLOR, J.C. \& Hamilton, P.B. (2017): Two new species of Achnanthidium Kützing (Bacillariophyceae) from Kolli Hills, Eastern Ghats, India. - Fottea 17: 65-77.

Kingston, J.C. (2000): New combinations in the freshwater Fragilariaceae and Achnanthidiaceae. - Diatom Research 15: 409-411.

Kingston, J.C. (2003): Araphid and Monoraphid Diatoms. - In: Wehr, J.D. \& Sheath, R.G. (eds): Freshwater Algae of North America. Ecology and Classification. - pp. 595-636, Elsevier Science.

Kobayasi, H.; Nagumo, T. \& MaYama, S. (1986): Observations on the Two Rheophilic species of the Genus Achnanthes (Bacillariophyceae), A. convergens $\mathrm{H}$. Kob. and $A$. japonica H. Kob. - Diatom 2: 83-93.

Kobayasi, H.; Idei, M.; Mayama, S.; Nagumo, T. \& Osada, K. (2006): H. Kobayasi's Atlas of Japanese Diatoms based on electron microscopy. - pp. 531, Uchida Rokakuho Publishing Co., Ltd, Tokyo.

Kociolek, J.P.; Balasubramanian, K.; Blanco, S.; Coste, M.; ECTOR, L.; LiU, Y.; KULIKOVSKIY, M.; LUNDHOLM, N.; Ludwig, T.; Potapova, M.; Rimet, F.; Sabbe, K.; Sala, S.; Sar, E.; TaYlor, J.; Van De ViJVer, B.; Wetzel, C.E.; Williams, D. M.; Witkowski, A. \& Witkowski, J. (2018) : - In DiatomBase. Accessed at $\mathrm{http}: / /$ www.diatombase.org on 2018-03-15.

Krammer, K. \& LANGe-Bertalot, H. (1991): Bacillariophyceae 4. Teil: Achnanthaceae, Kritische Erganzungen zu Navicula (Lineolatae) und Gomphonema. Gesamtliteraturverzeichnis Teil 1-4. - In: ETTL, H.; Gerloff, J.; Heynig, H. \& Mollenhauer, D. (eds): Süßwasserflora von Mitteleuropa., Vol. 2/4, - pp. 1-437, Gustav Fischer Verlage, Stuttgart.

KÜTZING, F.T. (1844): Die Kieselschaligen Bacillarien oder Diatomeen. - pp. 152, Nordhausen: zu finden bei W. Köhne.

Liu, B.; Blanco; S., Long, H.; Xu, J.J. \& Jiang, X.Y. (2016) : Achnanthidium sinense sp. nov. (Bacillariophyta) from the Wuling Mountains Area, China. - Phytotaxa 284: 194-202.

Marquardt, G.C.; Costa, L.F.; Bicudo, D.C.; Bicudo, C.E.D.M.; Blanco, S.; Wetzel, C.E. \& Ector, L. (2017): Type analysis of Achnanthidium minutissimum and $A$. catenatum and description of $A$. tropicocatenatum sp. nov. (Bacillariophyta), a common species in Brazilian reservoirs. - Plant Ecology \& Evolution 150: 313-330.

Novais, M.H.; Hlúbiková, D.; Morais, M.; Hoffmann, L. \& ECTOR, L. (2011): Morphology and ecology of Achnanthidium caravelense (Bacillariophyceae), a new species from Portuguese rivers. - Algological Studies 136: 131-150.

PARR, J.F.; TAFFs, K.H. \& LANE, C.M. (2004): A microwave digestion technique for the extraction of fossil diatoms from coastal lake and swamp sediments. - Journal of Paleolimnology 31: 383-390.

PÉrès, F.; Cohu, R.L. \& Delmont, D. (2014): Achnanthidium barbei sp. nov. and Achnanthidium costei sp. nov., two new diatom species from French rivers. - Diatom Research 29: 387-397.

Pinseel, E.; Van De Vijver, B. \& Kopalova, K. (2015): Achnanthidium petuniabuktianum sp. nov. (Achnanthidiaceae, Bacillariophyta), a new representative of the A. pyrenaicum group from Spitsbergen (Svalbard Archipelago, High Arctic). - Phytotaxa 226: 63-74.

Ponader, K.C. \& Potapova, M.G. (2007): Diatoms from the genus Achnanthidium in flowing waters of the Appalachian Mountains (North America): Ecology, distribution and taxonomic notes. - Limnologica 37: 227-241.

Potapova, M. \& Ponader, K.C. (2004): Two common North American diatoms, Achnanthidium rivulare sp. nov. and $A$. deflexum (Reimer) Kingston: morphology, ecology and comparison with related species. - Diatom Research 19: 33-57.

Round, F.E.; Crawford, R.M. \& Mann, D.G. (1990): The Diatoms. Biology and morphology of the genera. - pp. 747, Cambridge University Press, Cambridge.

Round, F. \& Bukhtiyarova, L. (1996): Four new genera 
based on Achnanthes (Achnanthidium) together with re-definition of Achnanthidium. - Diatom Research 11: 345-361.

TAYLOR, J.C.; MORALES, E.A. \& ECTOR, L. (2011): Achnanthidium standeri (Cholnoky) comb. nov. and Achnanthidium taiaense (J. R. Carter et Denny) comb. nov. two new combinations of morphologically similar Achnanthidium species from Africa. - Algological Studies 136/137: 151-166.

ViJVer, B.V.D.; Ector, L.; Beltrami, M.E.; HaAn, M.D., Falasco, E.; Hlúbiková, D.; Jarlman, A.; Kelly, M.; Novais, M.H. \& Wojtal, A.Z. (2011): A critical analysis of the type material of Achnanthidium lineare W. Sm. (Bacillariophyceae). - Algological Studies 136/137: 167-191.

Wojtal, A.Z.; Lange-Bertalot, H.; Nautiyal, R.; Verma, J. \& NAUTIYAL, P. (2010): Achnanthidium chitrakootense spec. nov. from rivers of northern and central India. Polish Botanical Journal 55: 55-64.

WoJtal, A.Z.; Ector, L.; ViJVer, B.V.D.; Morales, E.; LANZA, S.B.; Piatek, J. \& SmiejA, A. (2011): The Achnanthidium minutissimum complex (Bacillariophyceae) in southern Poland. - Algological Studies 136: 211-238.

Yana, E. \& Mayama, S. (2015): Two new taxa of Achnanthidium and Encyonema (Bacillariophyceae) from the Yom River, Thailand, with special reference to the areolae occlusions implying ontogenetic relationship. - Phycological Research 63: 239-252.

You, Q.M.; Kociolek, J.P. \& WANG, Q.X. (2015): The diatom genus Hantzschia (Bacillariophyta) in Xinjiang Province, China. - Phytotaxa 197: 1-14.

Yu, P.; You, Q.M.; Kociolek, J.P.; Lowe, R. \& WANG, Q.X. (2017): Nupela major sp. nov. a new diatom species from Maolan nature reserve, central-south of China. - Phytotaxa 311: 245-254.

Yu, P.; Kociolek, J.P.; You, Q.M. \& WANG, Q.X. (Accepted): Achnanthidium longissima sp. nov. (Bacillariophyta), a new diatom species from Jiuzhai Valley, Southwestern China. - Diatom Research. 


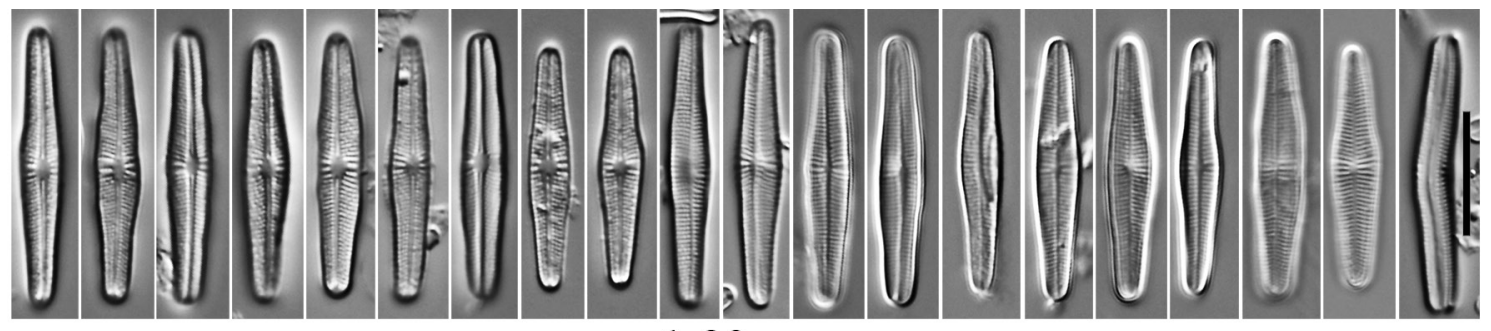

1-20

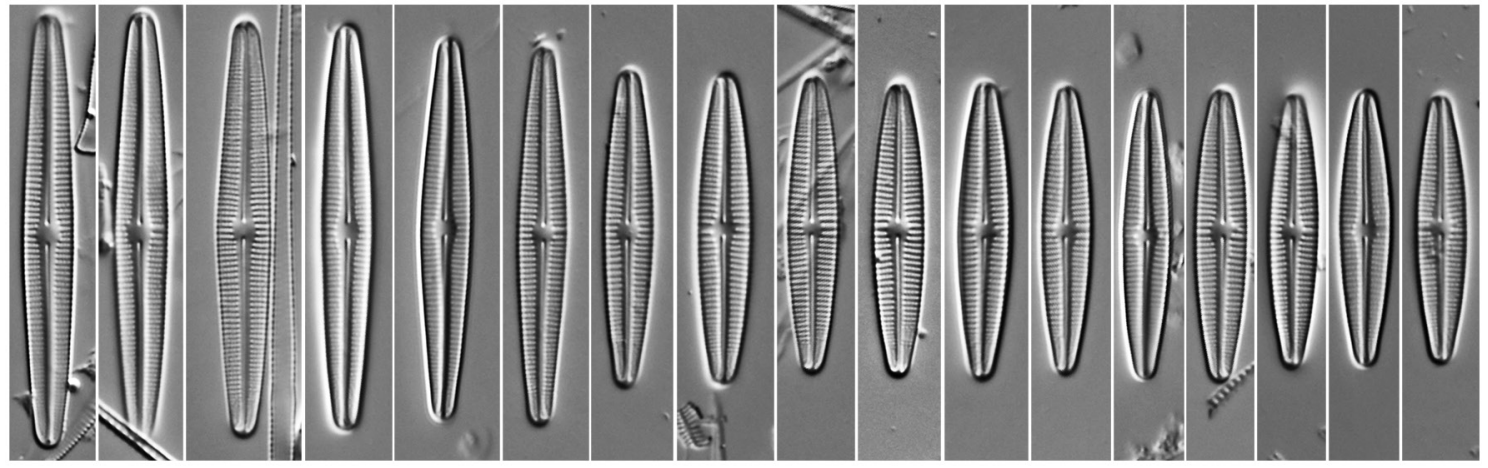

21-37
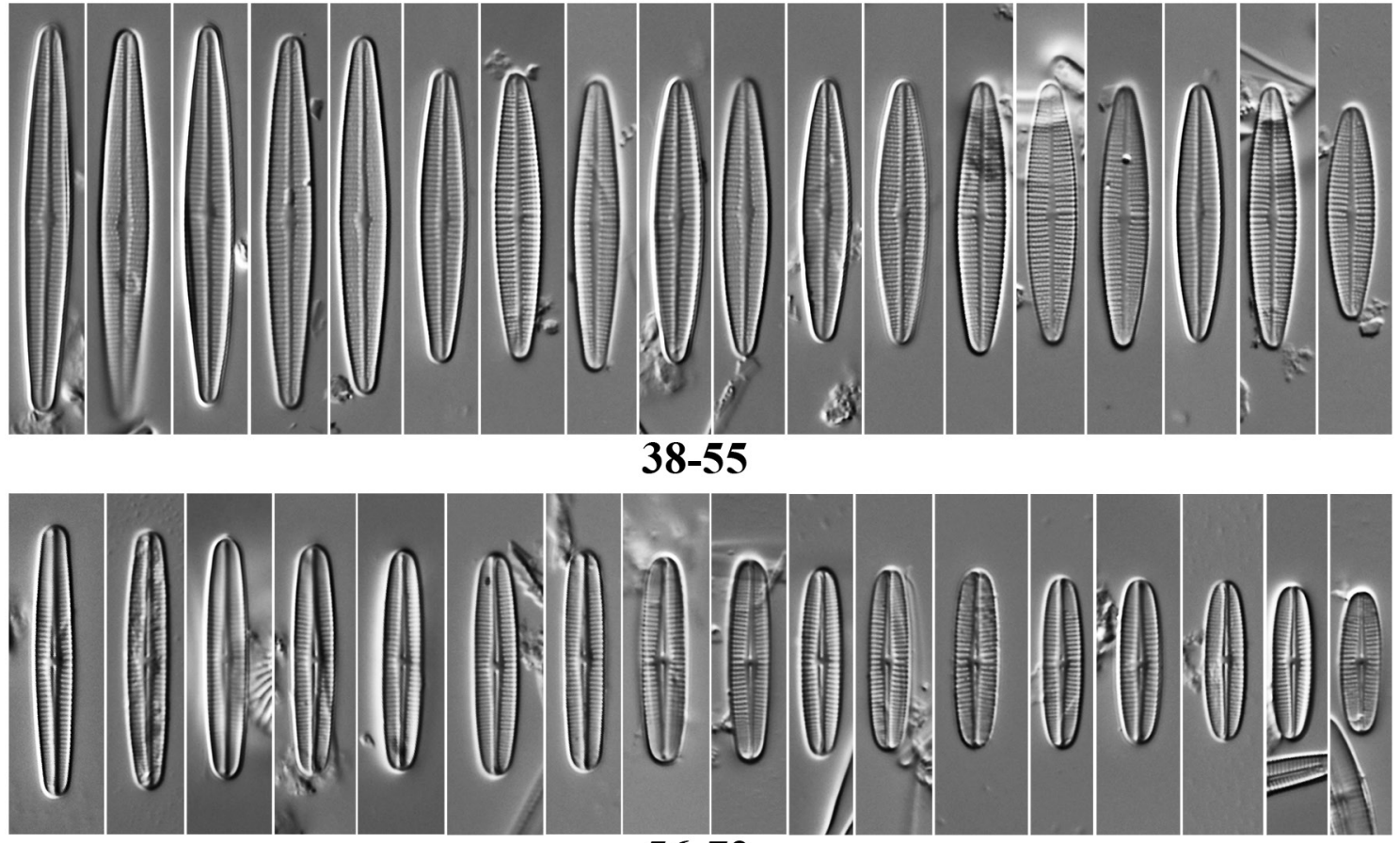

56-72

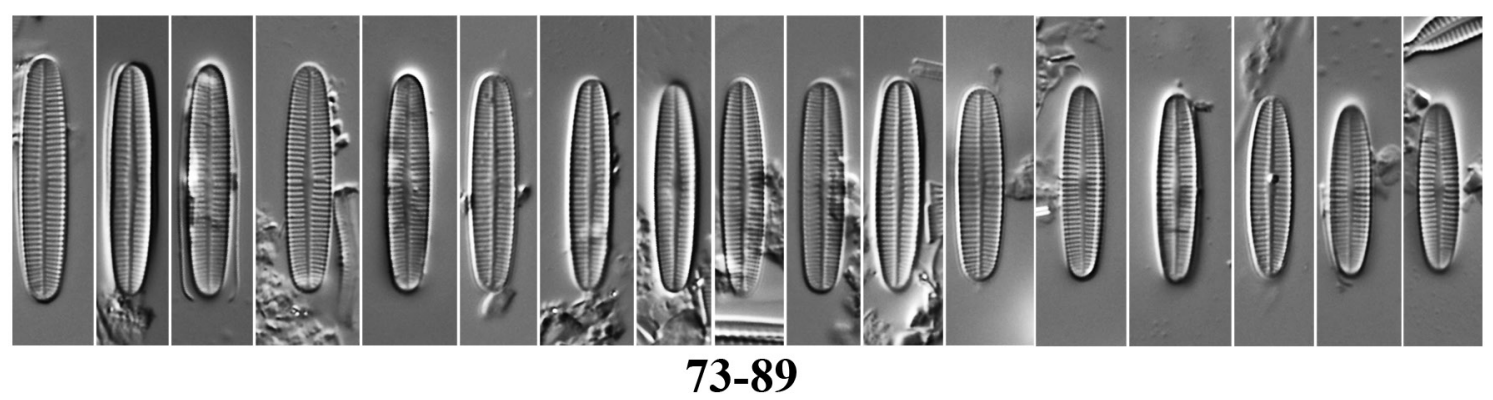

Figs 1-20. LM valve views of Achnanthidium lacustre sp. nov.: (21-55) LM valve views of $A$. sublanceolatum sp. nov., (21-37) Raphe valves, (38-55) Rapheless valves; (56-89) LM valve views of A. taipingensis sp. nov., (56-72) Raphe valves, (73-89) Rapheless valves. Scale bar $10 \mu \mathrm{m}$. 

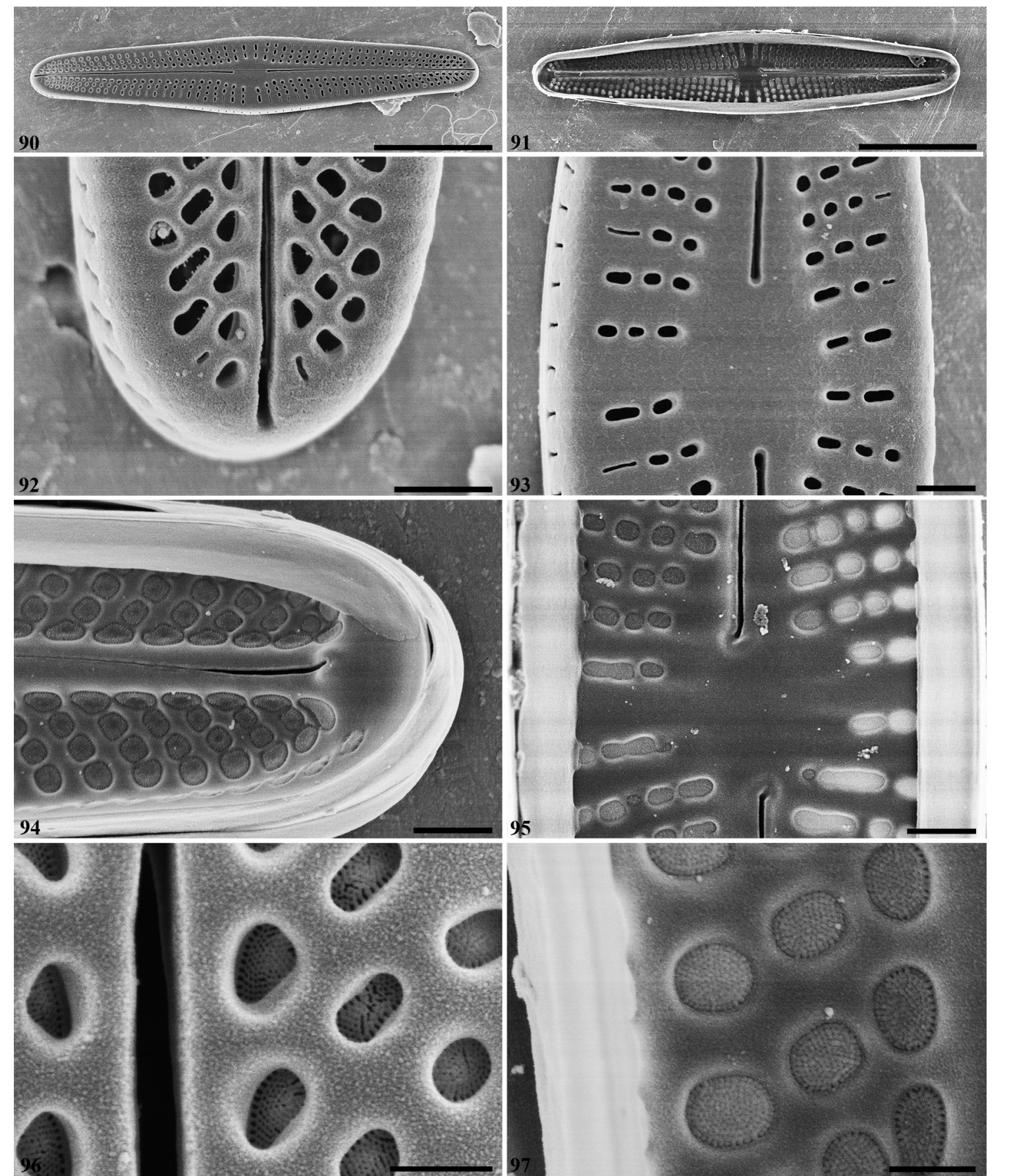

Figs 90-97. Achnanthidium lacustre sp. nov. SEM views of raphe valve: (90) External view of an entire raphe valve; (91) Internal view of an entire raphe valve; (92-93) Details of the apices and the central area on the external of the raphe valve; (93) Detail of the apices and the central area on the internal of the raphe valve; (96) Detail of the areolae on the external of the raphe valve; (97) Detail of the areolae on the internal of the raphe valve. Scale bars $5 \mu \mathrm{m}$ (90-91), $0.5 \mu \mathrm{m}$ (92-95), $0.2 \mu \mathrm{m}$ (96-97). 


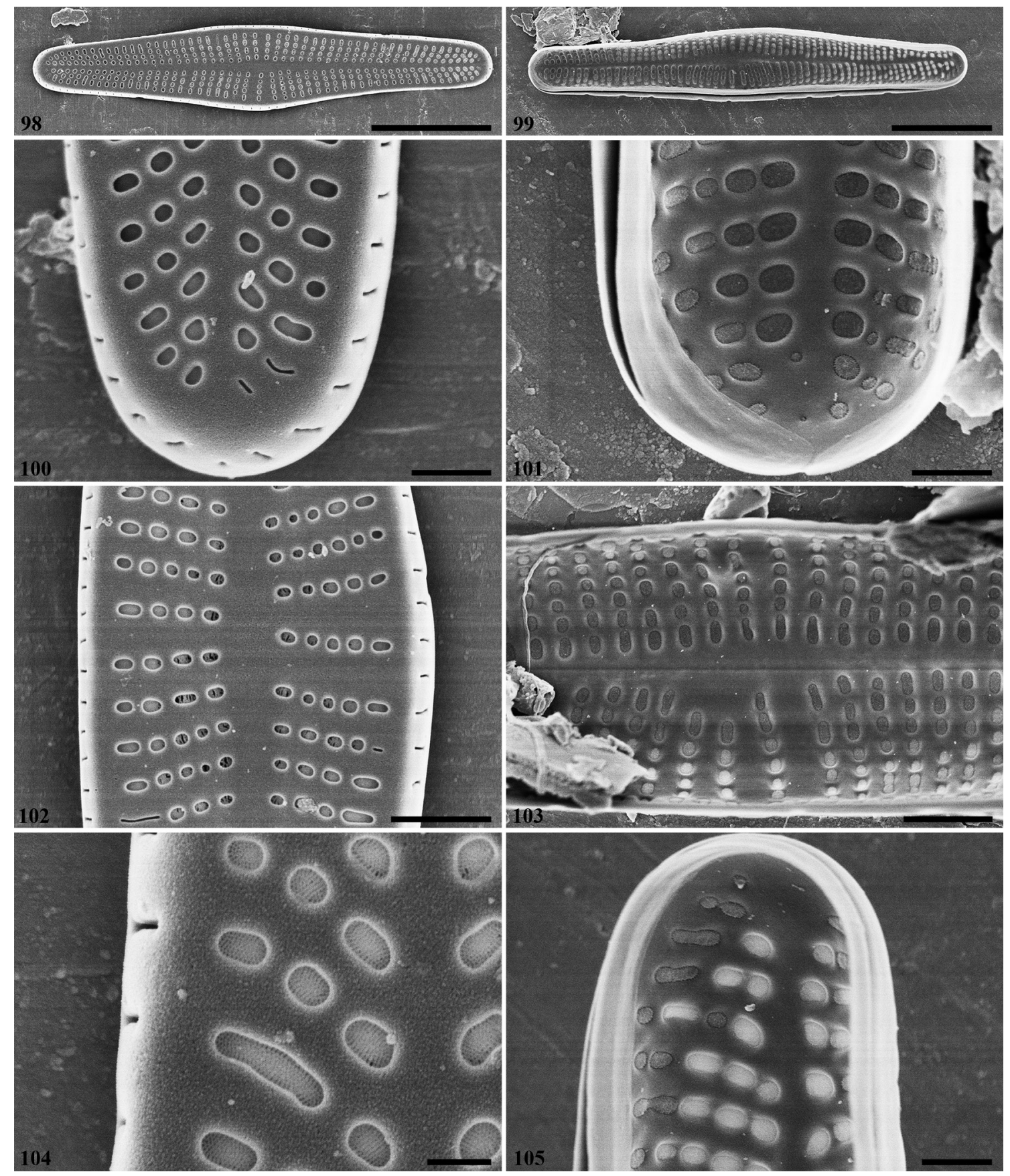

Figs 98-105. Achnanthidium lacustre sp. nov., SEM views of rapheless valve: (98) External view of an entire rapheless valve; (99) Internal view of an entire rapheless valve; (100) Detail of the apices on the external of the rapheless valve; (101) Detail of the apices on the external of the rapheless valve; (105) Detail of the apices on the internal of the rapheless valve; (102-103) Middle portion of the rapheless valve; (104) Detail of the areolae on the external of the rapheless valve. Scale bars $5 \mu \mathrm{m}(98-99), 1 \mu \mathrm{m}(102-103), 0.5 \mu \mathrm{m}(100-101,105), 0.2 \mu \mathrm{m}(104)$. 


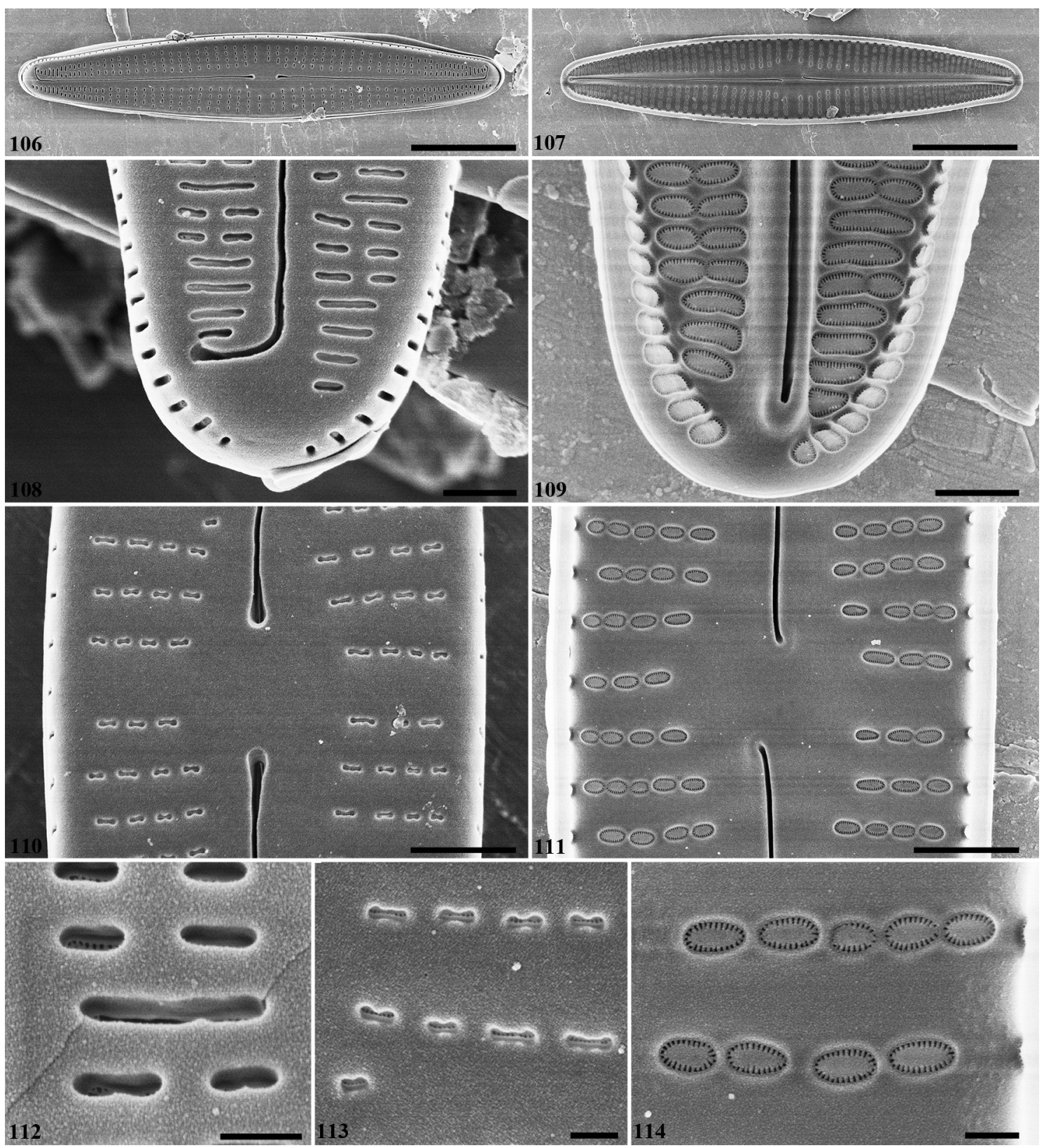

Figs 106-114. Achnanthidium sublanceolatum sp. nov., SEM views of raphe valve: (106) External view of an entire raphe valve; (107) Internal view of an entire raphe valve; (108) Detail of the apices on the external of the raphe valve; (109) Detail of the apices on the internal of the raphe valve; (110) Detail of the middle portion on the external of the raphe valve; (111) Detail of the middle portion on the internal of the raphe valve; (112-113) External areolae; (114) Internal areolae openings with fine hymenate structures. Scale bars $5 \mu \mathrm{m}(106-107), 1 \mu \mathrm{m}(110-111)$, $0.5 \mu \mathrm{m}(108-109), 0.2 \mu \mathrm{m}(112-114)$. 


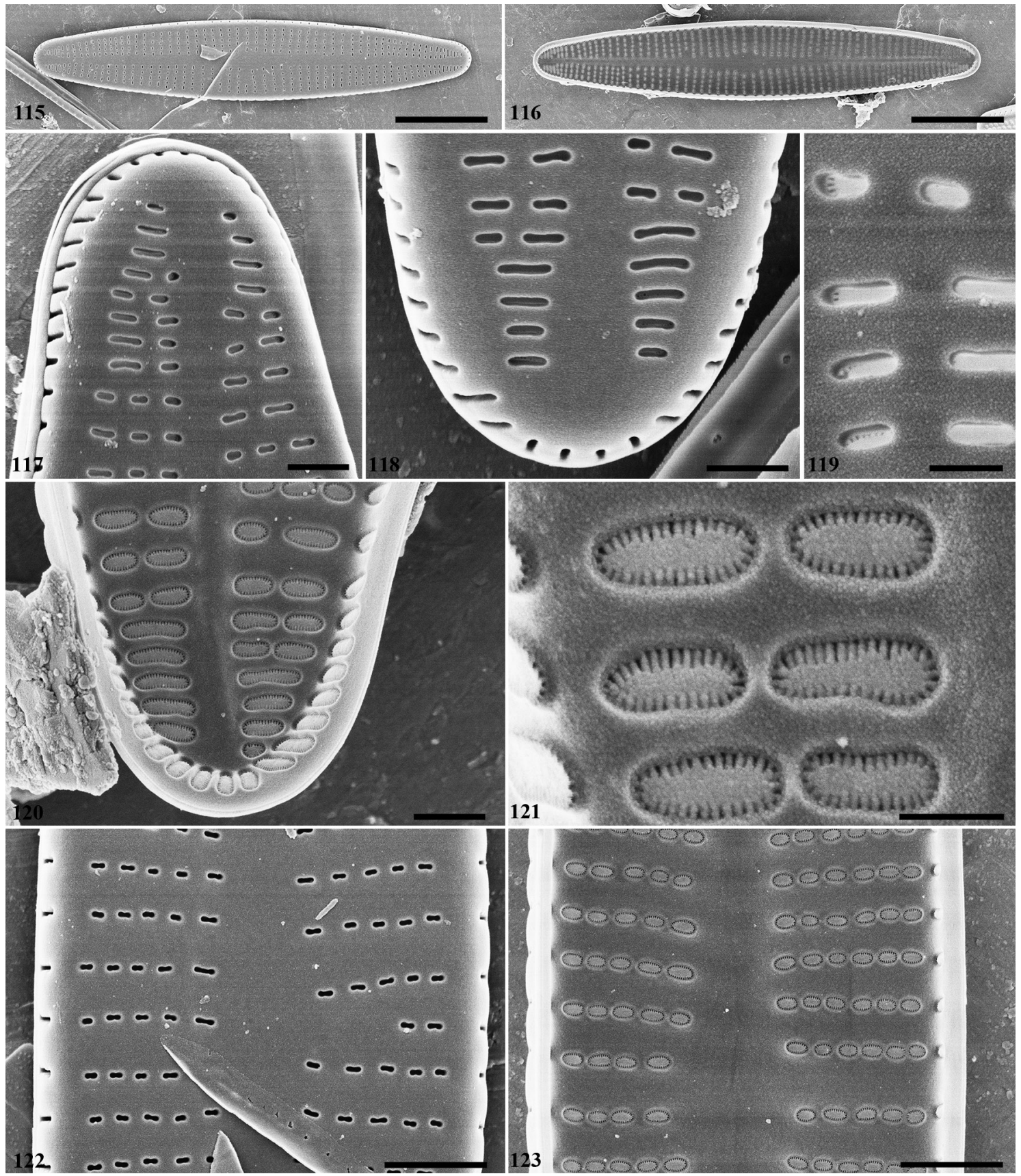

Figs 115-123. Achnanthidium sublanceolatum sp. nov., SEM views of raphe valve: (115) External view of an entire rapheless valve; (116) Internal view of an entire rapheless valve; (117-119) Details of the apices on the external of the rapheless valve; (120) Detail of the apices on the internal of the raphe valve; (121) Internal areolae openings with fine hymenate structures; (122) Detail of the middle portion on the external of the raphe valve; (123) Detail of the middle portion on the internal of the raphe valve. Scale bars $5 \mu \mathrm{m}(115-116), 1 \mu \mathrm{m}(122-123), 0.5 \mu \mathrm{m}$ $(117-118,120), 0.2 \mu \mathrm{m}(119,121)$. 


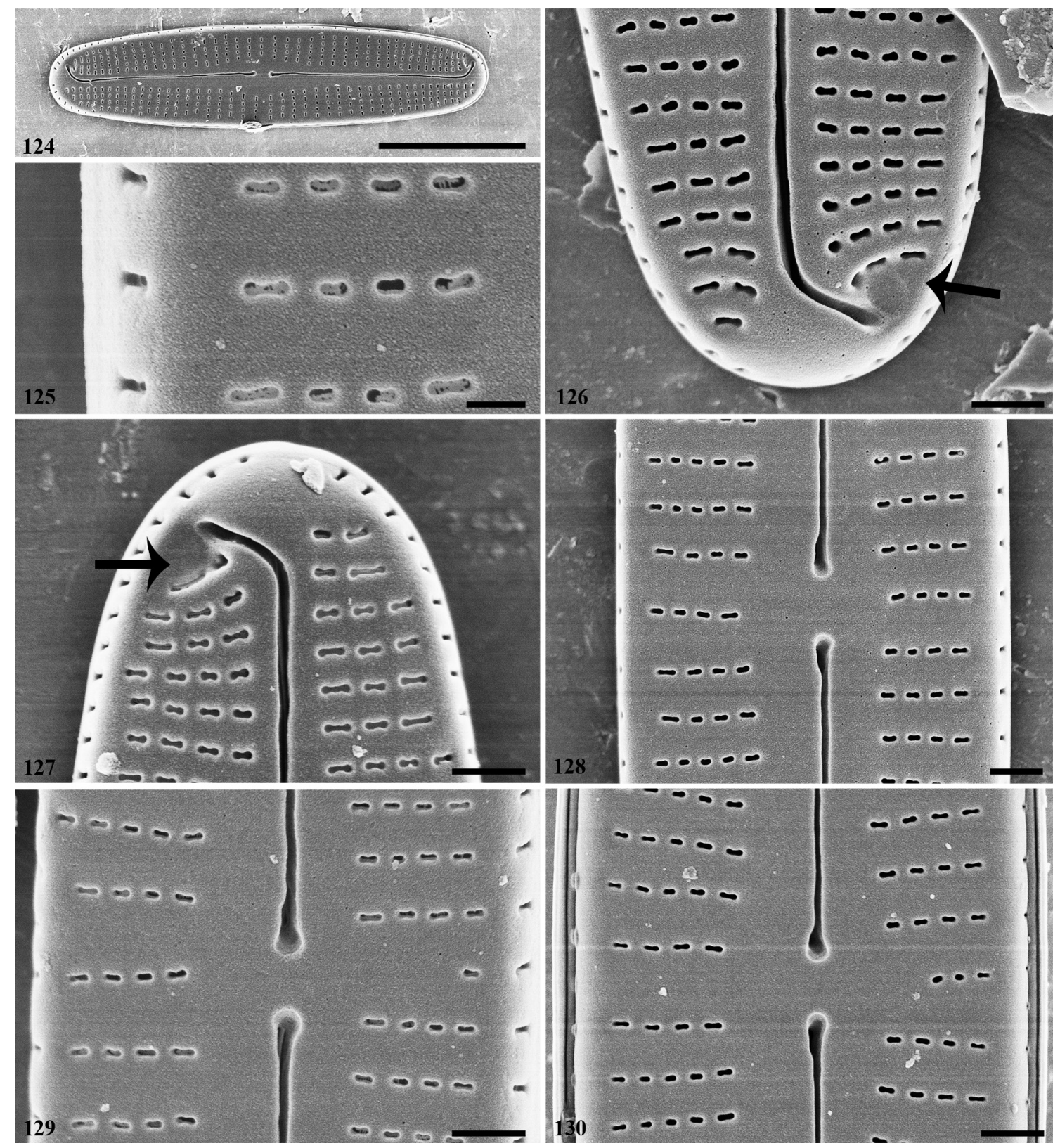

Figs 124-130. Achnanthidium taipingensis sp. nov., external views of raphe valve, SEM: (124) Entire raphe valve; (125) External areolae; (126-127) Details of distal raphe ends terminating on the valve mantle to form a drop-like areas, There is a depression near the terminal raphe fissures; (128-130) Details of the middle portion of the raphe valve. Scale bars $5 \mu \mathrm{m}$ (124), $0.5 \mu \mathrm{m}(126-130), 0.2 \mu \mathrm{m}(125)$. 


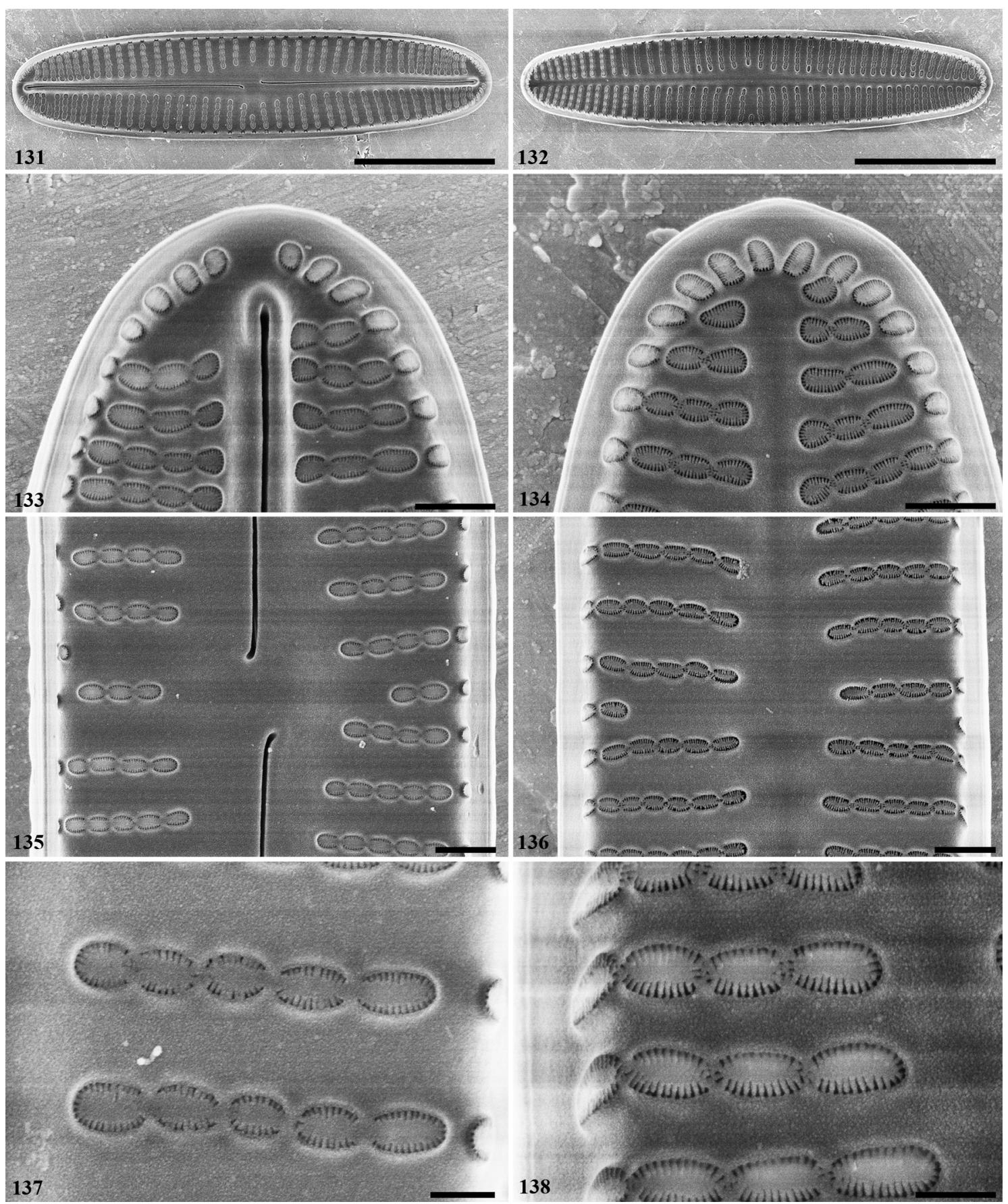

Figs 131-138. Achnanthidium taipingensis sp. nov., internal views of raphe valve and rapheless valve, SEM: (131) View of an entire raphe valve; (132) View of an entire rapheless valve; (133) Detail of the apices of the raphe valve; (134) Detail of the apices of the rapheless valve; (135) Detail of the middle portion of the raphe valve; (136) Detail of the middle portion of the rapheless valve; (137-138) Areolae occluded by hymens, which are partially merged with adjacent hymens. Scale bars $5 \mu \mathrm{m}(131-132), 0.5 \mu \mathrm{m}(133-136), 0.2 \mu \mathrm{m}(137-138)$. 


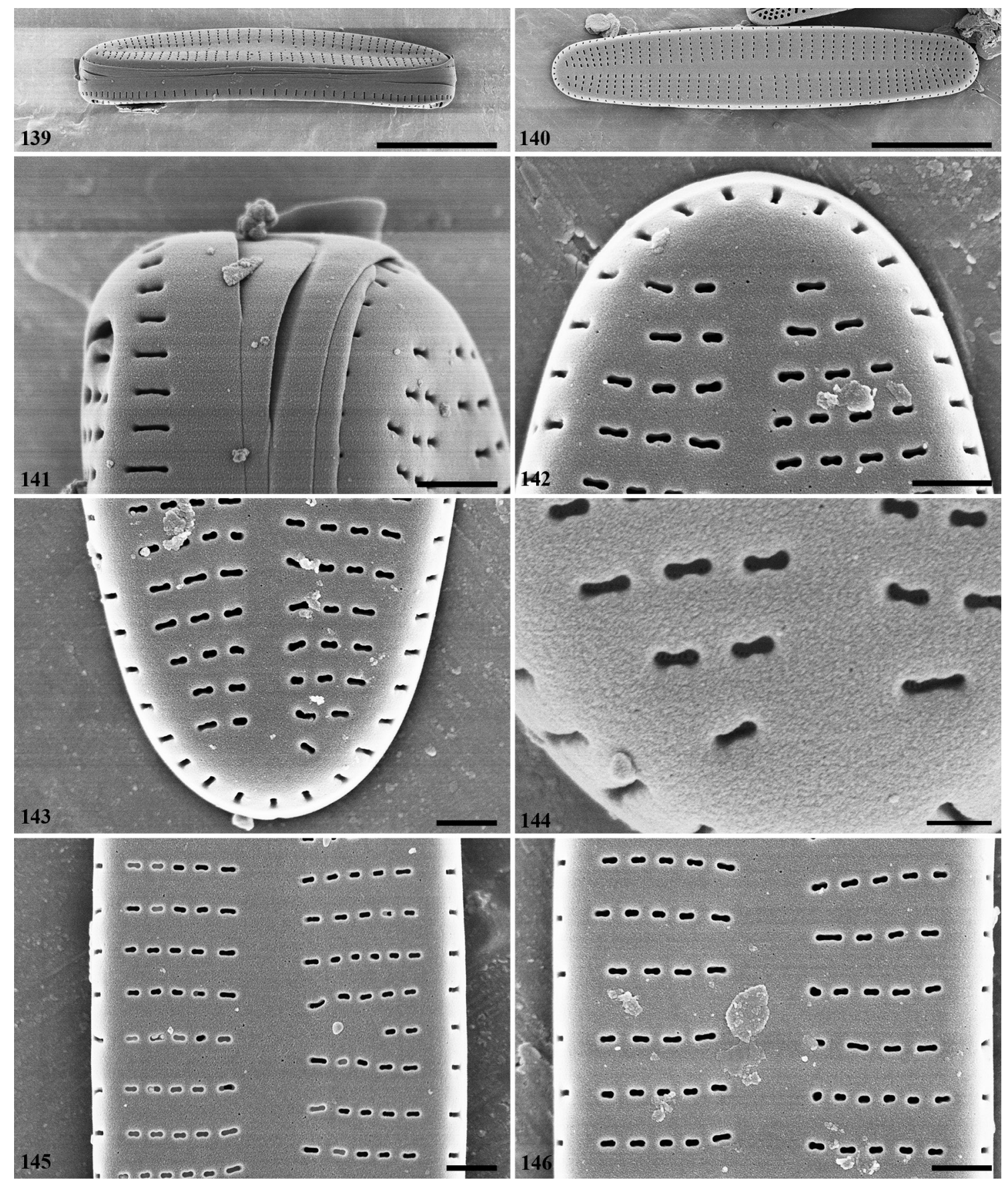

Figs 139-146. Achnanthidium taipingensis sp. nov., SEM: (139) Girdle view, a frustule with convex rapheless valve; (140) Entire rapheless valve; (141) Details of the apices of the girdle view; (142-144) Details of the apices on the external of the rapheless valve; (145-146) Details of the middle portion of the rapheless valve. Scale bars $5 \mu \mathrm{m}$ (139-140), $0.5 \mu \mathrm{m}(141-143,145-146), 0.2 \mu \mathrm{m}(144)$.

(C) Czech Phycological Society (2019)

Received August 10, 2018

Accepted November 28, 2018 